\title{
Miranda
}

Revue pluridisciplinaire du monde anglophone /

Multidisciplinary peer-reviewed journal on the English-

speaking world

13 | 2016

Thomas Spence and his Legacy: Bicentennial

Perspectives

\section{Forgetting and Remembering the Labor Plays of Manny Fried}

Essay

Barry B. Witham

\section{(2) OpenEdition}

Journals

Electronic version

URL: http://journals.openedition.org/miranda/9729

DOI: $10.4000 /$ miranda.9729

ISSN: 2108-6559

\section{Publisher}

Université Toulouse - Jean Jaurès

Electronic reference

Barry B. Witham, "Forgetting and Remembering the Labor Plays of Manny Fried", Miranda [Online], 13

2016, Online since 28 November 2016, connection on 16 February 2021. URL: http://

journals.openedition.org/miranda/9729 ; DOI: https://doi.org/10.4000/miranda.9729

This text was automatically generated on 16 February 2021.

\section{(c) $(1) \odot$}

Miranda is licensed under a Creative Commons Attribution-NonCommercial-NoDerivatives 4.0

International License. 


\title{
Forgetting and Remembering the Labor Plays of Manny Fried
}

Essay

\author{
Barry B. Witham
}

\section{Introduction}

1 As American democratic institutions, and indeed fundamental constitutional protections, are increasingly eroded by a seemingly insatiable plutocracy, it is important to unmask the strategies of what used to be termed the "Captains of Industry," but which are now known more colloquially as the "one per-cent." Elected representatives, shackled by ideology and awash in lobbyist cash, seem unable to restrain or obstruct the moneyed few who continue to make a mockery of representative governance. And the courts - even the so-called Supreme version often seem intent on enabling the process. In such a climate it is vital to probe the past in order to understand how we arrived here, and the labor plays of Emanuel "Manny" Fried, now almost totally erased from the American theatre, are extremely instructive in this regard.

One of the most wide-spread and popular tactics of the current plutocracy is the demonization of the American labor union movement. Not that this has been a particularly difficult task given the ways that organized labor has been complicit in its own eclipse. American workers are joining unions at the lowest rate since 1910. Statistics from the Labor Bureau reveal that only $11.3 \%$ of workers belonged to organized labor in 2012 compared to the high water mark of 35\% in 1954, and even nearly $20 \%$ in the Ronald Reagan era ${ }^{1}$. In the popular imagination, or perhaps the collective memory, labor unions are primarily responsible for the explosion of offshore work forces, unsustainable pension and medical programs and outmoded rules and regulations which protect unfit workers. While there is truth in all these charges and in several others including the proliferation of dozens of smaller special interest unions and the crippling bureaucracy of the AFL-CIO (American Federation of Labor- 
Congress of Industrial Organizations) - lost in the discussion is the fact that many of the benefits to the rank and file were negotiated by management, and by labor leaders, in exchange for "no strike" promises and overtime pay concessions.

The current slogan that encapsulates the attack on labor and the ongoing campaign by corporate America to subvert the union movement is "right to work." Like other previous assaults, right to work is clothed in patriotic garb and resonates with values that are prized by a majority of the citizenry. How could true Americans support a system which compels them to become part of group think and denies them their fundamental right of free choice? Right to work was recently adopted in Michigan that crucible of American labor - and is currently the source of a vigorous campaign in several other states. So it is instructive to interrogate this maxim in order to understand its popular currency and also to see how it functions historically as a strategy to combat and neutralize union formation and power. For millions of Americans, right to work is about fundamental and foundational values; for other millions it's about a "race to the bottom" in wages and yet one more assault on the American labor movement².

David Rolf has recently reminded us that "Seventy-five years ago, unions helped reinvigorate an economy decimated by the Great Depression. By the end of World War II, middle class families could afford a home, expect quality education for their children and enjoy secure retirements. Business boomed as the American middle class drove consumption and growth world-wide" ${ }^{3}$ That prosperity was ignited by several great union victories, the most important of which was the 1935 National Labor Relations Act which allowed workers to organize and bargain for a living wage and a better standard of living. Those victories and the celebrated battles that preceded them were important subject matter for the American theatre and produced a variety of productions that documented the bitter struggles of working class men and women. Black Pit (1935) with its horrific depiction of the poverty and exploitation in the coal mining industry; Stevedore (1934) with its expose of racial unrest and its triumphant embrace of organized labor; Marching Song (1937) with its canvas of abandoned Americans exposed to the brutality of the spies and the bosses; and, of course, Waiting for Lefty (1935) with its improbable but electric defeat of the gangsters who hijacked the union and the labor leaders who allowed it.

5 With the passage of the National Labor Relations Act in 1935, labor had been permitted to form unions and to negotiate for wages and working hours protected from company harassment. But management, especially in the big corporations and basic industries, supported by opponents of the New Deal and a coalition of Southern Conservatives was not about to bargain away position or power. Almost immediately efforts were made to amend, erode and destroy the Wagner Act. Bill after bill was introduced into the Congress to curb the legislation or to modify the National Labor Relations Board which was charged with carrying out the Wagner mandates. Management formed their own company unions, threatened and intimidated white workers by hiring Negro laborers, and employed thousands of strike breakers and industrial spies to undercut union credibility. The campaign to cripple organized labor never stopped and indeed intensified throughout the Second World War and in the great wave of strikes that followed the armistice. And even as the surging middle class brought a new quality in living standards, labor lost battle after battle culminating in the passage of the TaftHartley legislation in 1947 which legalized right to work provisions and further 
required that union officials must sign non-communist affidavits. This latter provision had a thunderous impact in the American labor movement and ignited years of redbaiting propaganda and slander.

6 The American theatre has not been nearly as articulate on the post Taft-Hartley world as it had been on previous working class victories and defeats. Despite the burst of populism during the long 1960s, the off-off Broadway depictions of late capitalism in the works of the Living Theatre, Teatro Campesino, Bread and Puppet, and later the brilliant voices of Tony Kushner, Suzan Lori Parks or Naomi Wallace, Americans seem to have lost interest in the struggles of the working class. Of course, working class experience has never been a central feature of the middle-class theatre industry, and any resurgent interest has to combat the wide-spread collective memory that the "New Deal" had been a failure. This view, which is still being hammered into American consciousness by numerous talk show hosts and conservative historians like Amity Shlaes, of course, conveniently ignores that the American economy roared back to life driven by the greatest government jobs programs in our history - war contracts for business and industry4. But Keynesian economics fell out of favor as did the travails of blue collar workers. In the nineteen nineties Norma Jenckes attempted to devote a special issue of American Drama to working class plays and performances but was unable to find sufficient entries 5 .

7 It was this absence which led me originally to the plays of Manny Fried. Emanuel "Manny" Fried died in 2011 just a few days shy of his $97^{\text {th }}$ birthday. He began his career as an actor, appearing in several Broadway plays as Edward Mann in the 1930s and earning accolades for his work with the "Theatre of Action" where he was directed by the young Elia Kazan. But he had strong union sympathies and after being recruited into the Communist party at Actor's Equity, he left the theatre to become an organizer in his hometown of Buffalo, New York. There he was a major figure in the epic battles to unionize Curtiss Aircraft, Westinghouse, DuPont and others. Dedicated to the rank and file and eager to win equal rights for women, Jews and blacks, Fried was proud of the fact that in 1941, when he joined with others to organize Curtiss, there were four blacks on the floor, all janitors. Three years later there were black union employees throughout the plant ${ }^{6}$.

8 Fried served with distinction in the army during the Second World War, and Kazan tried to coax him back to the stage and even offered him the "Karl Malden role" in his 1947 film Boomerang, but Fried returned to Buffalo to organize for the United Electrical Workers and the International Brotherhood of Machinists. For the next decade he was involved in a number of strikes, slowdowns and union campaigns which became the subject matter for his plays, stories and novels. In 1949 the UE (United Electrical Workers), in open defiance of both Taft-Hartley and intense CIO pressure, refused to sign the non-communist affidavits, subjecting them to scurrilous attacks. Fried was targeted and harassed by the FBI, who openly visited him and his neighbors, causing his two young daughters to be excluded on school playgrounds. The FBI also encouraged the Catholic Church to call for a boycott of his wife's business, and for competing unions to raid Fried's union shops ${ }^{7}$.

9 After a celebrated appearance before HUAC (House Committee on Un-American Activities) in 1954 where he refused to respond or even acknowledge the legality of questions about his politics, Fried was blacklisted and villainised by the FBI who had publicly christened him "the most dangerous man in New York State." Unable to find 
work in the United States, he sold insurance in Canada and wrote a series of plays chronicling his union activities and his harassment. Those plays - The Dodo Bird, Drop Hammer, Brothers for A' That, Elegy for Stanley Gorski - produced sporadically in labor theatres and off-Broadway in the 1960s and after, record a vivid period in trade union politics - especially in their depiction of the working class men and women who were instrumental in the struggle. And they serve as a caution as right to work gathers momentum again.

Unfortunately, Fried's plays have been largely erased from the canons of American drama and theatre, and their "forgetting" invites us to speculate about the causes of their erasure and the memories that they attempted to preserve. In describing his play Elegy for Stanley Gorski (1970), Fried called it "a detailed part of what life has been really like inside the labor movement - the secret history. And I write this out of my own personal experience. I lived it" ${ }^{\text {. }}$. Fried archived his memories as a Jew and a communist - exposing the red-baiting tactics employed by the CIO leaders which were widely responsible for purging of thousands of union organizers and patriotic working-class Americans. He is particularly scornful of the Catholic Church in the "cleansing" process and in the influence generated by the ACTU (Association of Catholic Trade Unionists). Elegy for Stanley Gorski (along with Drop Hammer) is drawn directly from Fried's organizing activities in Buffalo. When he arrived at Curtiss, workers were represented by an independent union called The Aircraft, which was rooted in seniority and was reluctant to embrace gender and minority reform. Fried led a floor revolt against the Aircraft petitioning worker support for the UAW (United Auto Workers). His efforts along with his comrade George Poole - proved so successful that according to labor historian John Olszowka, "they began gathering valuable evidence that not only discredited The Aircraft among Curtiss workers, but also provided the UAW with valuable information to eventually gain an NLRB (National Labor Relations Board) ruling ordering the disestablishment of the independent union". ${ }^{9}$

11 However, because of the huge defense contracts at Curtiss, army and CIO officials raised concerns about both Poole and Fried's communist associations, and Curtiss fired them. Though the action was clearly illegal, and Fried later sued and won a reinstatement, the UAW abandoned them rather than run the risk of being perceived as "controlled by communists." This red-baiting, which followed Fried for the remainder of his career and tormented thousands of other organizers, became a principle motif in the memory plays which he wrote during the sixteen years of his blacklisting and for three decades after. And that same red-baiting was a principle factor in helping to erase Manny's plays from the cultural memory.

\section{Elegy for Stanley Gorski}

Elegy for Stanley Gorski remembers the events at Curtiss as well as subsequent battles at Buffalo Bolt and Markel Electric. The play dramatizes the failure of a local Union to negotiate a just and fair contract for its members because the workers are misled and misinformed by competing ideologies and manipulated by a venal management. Gorski foregrounds the crusading issues that were important to Manny Fried and the core of his belief in union solidarity - equal rights for black workers, management recognition of working class men and women, and the devastating effects that red-baiting and McCarthyism had on the American labor movement. It is also powerful in its 
indictment of the Catholic ACTU, which was originally formed to advocate for working people but in 1947 had turned their attention almost exclusively to ridding labor unions of suspected communists. While scholars have been late to comment on or disagree about the impact of the Catholic voice in post-war Unionism, Fried is scathing in the picture that he paints of their tireless propaganda, red-baiting, and cronyism with management and Chambers of Commerce ${ }^{10}$.

It's clear why Fried calls his plays the secret history of the labor struggles because Elegy for Stanley Gorski remembers the campaign to keep Local 319 of the Machinists Union in a large industrial plant from being hijacked by a competing company-endorsed union. The stated reason for wanting to abandon the Machinists is because of "communist" influence and the preservation of jobs for the "senior members" of the local should management close the foundry or force the workers into an ill-timed strike. The rebels are opposed by Stanley Gorski who wins a contested election for President of the local. He is committed to the bread and butter issues of the workers, including a "seniority system" which will include long-term foundry workers, most of whom are black. Stanley's wife describes the foundry workers who will lose their seniority under a company union.

All those years in that foundry with that sand, that dust in their lungs. They pour that hot iron in there - some with burlap over their heads to keep out the heat and the black dust. That crane picks up these big pieces out of the ground and shakes out the sand and the dirt. All one big black cloud ... Stanley showed me where they were pouring the hot iron. You look through the door from the street and it looks like something out of hell ${ }^{11 !} ! !$

Gorski, like so many of Fried's characters is rich in strengths and foibles. He runs a little gambling operation on the side, has an annual stag film night---for which he pockets the proceeds---and is unfaithful to his wife. However, he is devoted to the welfare of his workers, is capable of standing up to management and understands the necessity of treating Negroes as equal partners in the system. For Stanley the charges of communism are just red baiting and McCarthyism.

Stanley is supported in his efforts by Dave Sigmund, a union organizer and a thinly disguised version of Fried himself, who is Jewish and communist and a supporter of shop floor democracy and rank and file rights. Dave Sigmund has a more sophisticated understanding of management tactics and the threats of plant closings, automation and work stoppages. He is smart enough to recognize the politics behind the drive to decertify the local union. What he doesn't realize at first is how the whole campaign to decertify is being driven by a plot among management, labor spies, the FBI and the Catholic Church. ${ }^{12}$

16 Early in Fried's play, Father Hogan, a "labor priest" cautions Stanley about the difficulty that Dave Sigmund will pose if Stanley continues to seek his advice:

FATHER HOGAN: You believe that he's doing a good job for the workingman. He is.

And that's why he's so very dangerous.

STANLEY: Because he's a smart Jew on our side?

FATHER HOGAN: Whose side is that?

STANLEY: The workingman.

FATHER HOGAN: A dupe. Being used. An honest dupe. The worst kind. The most dangerous. And it's unfortunate that he's Jewish. It makes it look like we are antiSemitic. I hate Anti-Semites! Scratch an Anti-Semite and you'll find an AntiCatholic! It's not that Davey Sigmund is Jewish. But a shop almost seventy-five per cent Catholic, we are entitled to a leader here. Someone like you. The labor 
movement is too important to be under the leadership of anyone but the Church. No matter how honest, we can not permit leadership to remain in the hands of one who is or who once was a member of the C.P.U.S.A., and who still refuses to denounce them publicly ${ }^{13}$ !

17 Stanley, who believes that Dave, like him, is a genuine supporter of the rank and file, is pressured by the priests and by his wife, whom the priests have lobbied to create suspicion about Dave's religious beliefs and his loyalty to America. In a scene reflecting Fried's own experiences in Buffalo, Dave is confronted by Stanley who articulates the gossip that the church has been spreading:

STANLEY: . . . But first I want to say this. Personally, Davey. In front of a witness. I like you, you sonofabitch. You're smart. And it would be nice to have you in my corner. But as long as I'm president of Local 319 no outsiders are going to dictate to this outfit. The Republican Party ain't going to dictate! The Democratic Party ain't going to dictate. And no Communist Party ain't going to dictate neither!

DAVE: I agree. And let's go one step further, Stan. This complicated labor game everybody trying to control it and use it - only one way to develop trust. Bring it out in the open and sweat it through. Please believe me, I mean nothing against you or your religious beliefs. But while I'm working with Local 319 - I'm not sure how long that will be - I'm going to fight to keep any Jewish rabbi from outside dictating. And no Protestant minister from outside. And no Catholic labor priest from outside neither ${ }^{14}$.

Here is classic Manny Fried. The union should belong to the rank and file and not to the officials who themselves have become big business and have lost sight of the worker's interests. There are echoes of George Meany's famous declaration that he never went on strike in his life, or Dave Beck's assertions that unions are big business, or John L. Lewis' betrayal of the mineworkers by allowing management a free hand in automating the mines. On Dave's advice, Stanley resists management's attempts to close the foundry and fights for the seniority of the black workers. He confronts the president, Mr. Goodyear, who appears to back down, and Stanley's courage endears him to the men who elect him president of the local. Shortly after, however, Stanley is offered a position in the diocese by the Priests as a reward for keeping the union out of a strike action. He does not understand that he has been duped by the church, and that they have colluded with management from the outset to elect Stanley to the Presidency so that they can red-bait and destroy the current union:

STANLEY: Come on! Before the election who took everybody up there and made him take down the notice?

FATHER HOGAN: And who do you think it was who telephoned Mr. Goodyear not to fire you? Not to call in the plant guards? Not to say get the hell out of here, you're fired? To take down the notice until after the election and give you the great victory which elected you president of the Local?---Who do you think did that?

STANLEY: You set me up, you set me up!

FATHER HOGAN: To clean out the red in there ${ }^{15}$ !

Stanley refuses to resign and take the offered job in the dioceses and is fired. Confident that he can file for reinstatement, he watches the new "non-commie" union turn their back on him. Dave is purged and Stanley is unemployable. He tells the labor priests:

STANLEY: Father, I want to tell you, and you remember. Next time you see me come in again inside your church it'll take six men to carry me in - feet first in a box! Nice to know all you good lovely people. (TO FATHER HOGAN) Give my love to Mr. Goodyear. (TO FATHER KUBIAK) And tomorrow morning Mass in your church Father, you light a great big black candle for $\mathrm{me}^{16}$ ! 


\section{promise of a better world. Stanley, betrayed and then abandoned by his union,} estranged from his wife and troubled marriage, dies bewildered and bitter. Fried had no illusions about the lengths that corporate America would go to confound the labor union movement. The great resurgence of rank and file activity in the 1970's for a time encouraged him, but the politics of union leadership in aligning themselves with the Nixon administration and the final popular support for Reagan's destruction of the Air Traffic Controllers confirmed his belief that the Captains of Industry still ruled America. Fried continued to write and speak out against management's tactics of patriotic appeal, still the weapon of choice, and reminding us that Right to Work (with its fervent Christianity) rose to prominence in the South in the 1930s when labor unions and Jews threatened segregation. And again thirty years later in the wake of renewed civil rights, Martin Luther King warned that "we must guard against being fooled by slogans such as "right to work." It robs us of our civil rights and our job rights. Its purpose is to destroy labor unions and the freedom of collective bargaining". 17

Like many of Fried's plays, Elegy for Stanley Gorski has a complex production history. Originally titled Brother Gorski, it was optioned for an Off-Broadway production in 1972. But difficulties between Fried and the producer over content, language and royalty rights led to compromises on Fried's part which he came to regret. The play went into rehearsal, and Fried continued to re-write although he felt like he was "gutting" the play. Finally in a tense showdown, the producer made additional requests for changes which Fried refused. With an opening date set, the producer quit, and the play opened at the Astor Place Theatre on March 15, 1973 with the Brother Gorski Company listed as producer. It was a disaster. Brother Gorski ran for six performances and disappeared. Clive Barnes wrote that "it was well meaning but excessively heavy-going. Mr. Fried's heart is in the right place, but his playwriting isn't". ${ }^{18}$ And Allan Wallace concluded that "There may be a good play in the subject of the politicization of a working man, but we'll have to wait for it". ${ }^{19}$

Fried continued to work on the play - among many other projects - and restored the "working-class" language that had gotten homogenized in New York, and sharpened the critique of the church, which had also been blunted for "commercial purposes." Following the success of Drop Hammer in Los Angeles, Fried, who was now teaching creative writing at Buffalo State University, was approached by a local theatre company to produce the revised play. He changed the name to the current title so as not to confuse it with Brother Gorski, and the Buffalo Center Theatre gave it an uneven but striking production in January, 1981. Buoyed by all the local references and characters - and still red-baited by some of the press - Elegy for Stanley Gorski was handsomely reviewed and produced. Writing in the Tonawanda NEWS, Lou Michel reviewed the historical episodes which inspired the writing and after touching on the red-baiting of the UE and the wars with the IUE and the machinists, told his readers, "But enough. Go and see it. It's a play that has local roots and shouldn't be missed by anybody who's ever worked a day in his or her life". ${ }^{20}$

There was renewed interest, but the demands of the play, especially the large interracial cast and its decidedly working-class focus, discouraged commercial producers. Following Fried's death in 2011, however, there was renewed interest and amongst the laurels that came his way was the dedication of a theatre space named in his honor. 
Fittingly, it is in a huge old factory with roots in Buffalo's working class industries. Today, it is occupied by the Subversive Theatre Collective whose director Kurt Schneiderman was an admirer of Manny Fried. In March, 2012, he staged a rousing revival of Elegy for Stanley Gorski which inspired one critic to write: "As I watched the play, I couldn't help wonder what kind of career Manny might have had if blacklisting hadn't prevented him from getting high-profile productions of his plays. . . At the conclusion of the evening, the play, its issues, and its playwright continued to resonate powerfully in my mind". ${ }^{21}$

\section{Drop Hammer}

Unlike Elegy for Stanley Gorski, Fried's Drop Hammer comes to us buttressed by a thoroughly professional and stunning production. In the mid-1970s, frustrated by the FBI campaign to discourage support for his writing, Fried had founded his own press (Labor Arts Books) in hopes of distributing copies of his plays to sympathetic critics and producers. He sent a copy of Drop Hammer to Dan Sullivan, the influential theatre critic for the Los Angeles Times, who read the script carefully and liked it. On September 27, 1977, he wrote to Fried that he felt uncomfortable "doing a blurb" for a play that he hadn't seen in production but he offered an appraisal of Fried as a writer:

No American playwright writes so knowledgeably and so sensitively of labor's rank and file as Emanuel Fried. He knows what drive workingmen and their families, their fears, their sense of honor. He knows the things they can say to each other and the things they somehow can't bring themselves to say. And he never preaches. This is a people's playwright who can see the individual face ${ }^{22}$.

But more importantly, Sullivan sent the play to the Los Angeles Actors Theatre, a company he admired and who "have a special interest in blue-collar plays". ${ }^{23}$

LAAT at the end of the 1970s was on a mission to become an important theatre in the Los Angeles community; to wrestle some sheen away from the prestigious Mark Taper Forum and to make live theatre relevant in the movie-centric community. Under the direction of Bill ("Bush") Bushnell, the Actors Theatre embraced the emerging multicultural sensibilities of the day as well as the quest to find new and invigorating writers for the American Theatre. Bushnell, an inspiring and controversial director and producer, had plans to grow his theatre into a west coast version of Joe Papp's Public Theatre in New York. He imagined a vibrant multi-stage venue in the heart of downtown L.A. featuring black and Puerto Rican plays as well as re-imagined classics and original works, alongside art galleries and coffee shops, to attract audiences to the problematic east side. He was talented and sometimes abrasive, but he sold his vision to the mayor and the arts commissions and the moneyed aristocracy, and in 1985 he opened the Los Angeles Theatre Center with robust publicity and critical panache; a physical representation of what he had been dreaming and promising to all who would listen.

Bushnell was intrigued by Drop Hammer and scheduled it for a forthcoming season. He recognized the importance of the subject matter to the local communities and the authenticity of the union environment and dialogue. Eventually he engaged a first-rate team of artists - including a cast of thirty - to capture the drama and tensions of the union meetings which are at the core of the drama. Sullivan was delighted with the 
impending production, and in his opening night review he recorded his history with the play/

I walked up the stairs of the Los Angeles Actors Theater last weekend feeling a bit on trial. The play was "Drop Hammer" by Emanuel Fried - a script I'd suggested the theater read two or three seasons back. How would it look in performance? Three hours later, I wasn't sorry I'd made the introduction. "Drop Hammer" plays as it reads - forcefully, clumsily, sometimes; movingly, in the end ${ }^{24}$.

Sullivan's praise was echoed by others and insured the play's successful run. William Murray wrote, "Crudely eloquent and powerful, unfailingly honest in its observations, it is exactly the sort of play Odets might have written if, like Fried, he had ever actually worked in a factory. Drop Hammer is to Waiting for Lefty as Das Kapital is to the works of Horatio Alger". ${ }^{25}$ In his memoir, Most Dangerous Man, Fried recalled that, "for the first time in its history, with unions buying large blocs of seats for their members, the Los Angeles Actors Theatre sold out all seats for the entire run of the play". ${ }^{26}$

In many reviews Fried was frequently compared with Clifford Odets, but that comparison speaks more to the absence of genuine working class theatre in the American canon rather than similarities between the authors. Here, for example, is Fried's remembrance of the Waiting for Lefty premiere in 1935:

The play was hailed then as a strongly pro-labor play because the taxi drivers overcome their fears and vote to stay on strike ... It was then moved to a Broadway theatre where it was strongly supported by the essentially middle class and upper class audiences. Years later, having become a union organizer working with blue collar workers in heavy industry, I recognized that the majority of the taxi drivers presented in the play had formerly been middle class white collar professionals who felt that the conservative establishment had punished them for their radical ideas, forcing them down from the middle class into the working class, where they hated that they were now "ordinary" members of the labor class, driving taxicabs ${ }^{27}$.

Odets has a certain romance with and about his working-class heroes and heroines; the good little people struggling against an oppressive capitalist system. Fried has very little romance. His rank and file men and women are playing against a stacked deck, fighting for the preservation of their union and their way of life in the face of management which continually oppresses them. That oppression is visceral in Drop Hammer where we hear before the curtain raises, "Factory noises: clank and squeal of box cars pulled by yard locomotive, drawn-out metal against metal sound of overhead yard crane straining as it shifts heavy load, grinding and hum of batteries of machines cutting and shaping metal, steady rhythmic pounding of giant drop hammer". ${ }^{28}$ The drop hammer sound continues throughout the play, punctuating the action and reminding us of the corporate power that threatens the stability of the union. The setting is a bar across the street from the factory and like many of Fried's plays, the characters struggle with drink and broken promises and damaged relationships. The time is the 1950s but the comparisons to Odets frequently thrust the reviewers back into invoking a 1930s mindset where the labor battles were foregrounded. Fried's concerns, however, have grown beyond the right to organize and invoke a 1980s warning of things to come. Hovering over Drop Hammer is the threat of mechanization, the move to more welcoming southern "right to work" states and the internal corruption generated by an abundance of union dues. And, of course, the ever present "red-baiting" which now justifies stealing from the "brotherhood."

31 Drop Hammer is based Fried's work organizing for the UE at the Blau Knox foundry and machine shop in Buffalo in 1952. It was a particularly stressful and nasty campaign 
because the Buffalo press was openly antagonistic to Fried and constantly badgered him for comments and interviews about his "communist associations." This is perhaps why Fried puts himself so actively into the events of the play. For here again, we encounter Dave Sigmund, the alter ego who helps to expose the Catholic Church treachery in Elegy for Stanley Gorski. But this Sigmund is fleshed out more so that we also encounter Fried's aristocratic/painter wife, Rhoda, and the tensions that haunted their marriage. After he was blacklisted Fried was able to survive for a while on money from her father's family, and this was often invoked by his enemies to discredit his workingman credentials and undermine his relationship with the rank and file. In Drop Hammer Dave Sigmund is victimized by the same gossip and slander.

The play begins with a grievance by one of the lathe operators because he is being paid less than others doing the same job. Although the difference is only a few cents per hour, and the company has disagreed with the job description and category of work, his steward and others want to press for arbitration to settle the matter. Arbitration, however, is expensive, and is being debated among the rank and file because the treasurer, Carl Morgan, considers it a diversion. Their attention, he argues, should be on rumors that the company is going to move the plant to a new location in Kentucky. At which point no one will have a job. His opponents, however, view this as Morgan's attempt to change the subject, and perhaps mask the fact that he has been stealing from the treasury. The familiar Stanley Gorski is also here, and having been the treasurer just prior to Morgan, bristles at the suggestion that the books he turned over to Morgan were cooked in any way.

CARL: Sir! Did it ever occur to you that you might be looking in the wrong place for the wrong thing? When Kentucky opens full blast? Every penny grievance wiped out! Nothing to arbitrate.

STAN: The guys want to know. Is the money there now to arbitrate Eddie Bennett's grievance?

CARL: Sir! My first year as financial secretary. I inherited this situation.

STAN: The treasury was in good shape -

CARL: On paper!

STAN: Bullshit! The books -

CARL: Two out of three sign every check! The treasurer! Myself! (Pointing to Stan) Or one other officer.

STAN: (Leaping to feet) You sonofabitch, if you're accusing me - you better prefer charges ${ }^{29}$ !

Fried focuses the action now on embezzled funds; one of the most prominent issues that plagued union politics in the post-war decades, and one of central concerns to him as an organizer. The scandals that accompanied the financial corruption in organized labor not only made front page headlines, but in the estimation of many, led to the diminishment of labor in the public eye and the eventual demonization that persists to the present day. The link between labor unions and organized crime was forged during the bitter and violent organizing days at the beginning of the twentieth century. Companies hired goons and professional strike breakers to attack striking workers, and the unions retaliated by hiring "toughs" of their own. Thus gangsters infiltrated the rank and file, placed "officers" in key positions, gained access to lucrative dues pools, ran their protection rackets, and were in place when the big unions began negotiating generous pension plans after the Second World War. on the employer to make payments to such funds on behalf of the employees. 
According to federal law, the funds would be managed by equal numbers of uniondesignated and employer-designated trustees. In practice, the employer appointed trustees deferred to the union trustees because (in contrast with the union) having made the contributions, the employer had little interest in how the money was invested or spent. Racketeers embezzled the assets of pension and welfare funds by disguising thefts as "loans" payments for non-existent goods and services ${ }^{30}$.

The upshot was astonishing. Organized crime used union dues pools and pension funds as banks from which they financed hundreds of quasi-legal and illegal enterprises. They paid salaries for non-existent jobs, spent lavishly on their own officers and confidants, bribed management employers to advance union positions, set up phony companies and unions and even financed the building and operation of casinos in Las Vegas. The Teamsters were the most vulnerable, along with Hotel and Restaurant Workers, Construction and Garbage, but the corruption of union monies was wide spread. Manny Fried was vehement in his belief that dishonest union officials, tempted by access to easy money, constantly threatened the effectiveness of the union movement.

In Drop Hammer he uses rumors of stealing to show how Carl is discredited among the work force, and then how Carl tries to turn the tables by suggesting that the books were cooked before he ever became treasurer. He confronts Stanley about where the books were audited:

STAN: (Yells) In my house! What the hell's that -!

CARL: In your cellar where you got your fancy bar which cost plenty to install.

STAN: I installed it myself.

CARL: Your own bar? Your own stools? Your own shiny plated fixtures? - Who paid

for all the beer and sandwiches?

STAN: For all the work the trustees do for nothing we owe at least that!

CARL: They didn't give even one look to those damn books!

STAN: They looked, they looked!

CARL: You read off the books - the checks - the vouchers! They wrote down and added your figures! They checked nothing! They were too damn busy sucking up beer bought from the treasury! - that was supposed to be for our membership after our meetings! - here! ${ }^{31}$

Stan then challenges him to prove his charges in front of the membership and to explain why the treasury won't support the arbitration case that the members have voted to pursue. As International representative, Dave Sigmund's job is to move the arbitration case forward because the rank and file has voted to authorize it. Carl argues that it's silly to focus on this at a time when the whole union will be in peril if the work is moved to Kentucky. He wants to use the meeting to argue for direct action, a wildcat strike if necessary, to forestall a company move, or perhaps to have first call on jobs in Kentucky as well as severance pay and protection of pensions. Stan believes that Carl's reluctance has nothing to do with Kentucky, but is only a further attempt to cover up his stealing. Their positions ignite the union meeting which follows.

With the full membership in attendance, Fried wrenches the play away from the charges of theft and into the more explosive issue of red-baiting which nearly split the membership three years earlier. At that time Carl was Dave's close friend and confidant and prevented their colleagues from deserting to a competitive IUE local. Those old enmities now re-emerge in the contentious meeting where the argument is about stealing, but where the real issue is revenge on Dave Sigmund and the "commies." Fearing that Dave will stir unrest among the rank and file over the plans to move the 
plant, management tries to re-smear him with the commie charges, and even manipulate Carl's wife into denouncing him in front of the collective gathering.

MILDRED: (Dramatically stepping forward, pointing to DAVE, screaming) Him! He's the guilty one! Him! He's the one comes over to the house and gives my husband the orders from the commonists to tell him what to do!

CARL: (Overlap, on feet) You stupid bitch! G'wan home.

ENSEMBLE: "She's out of order." - "Throw her out." - Etc.

STAN slams gavel.

OTHERS: "Let her talk." - "The truth." - Etc.

MILDRED: (Without break, voice rising to fierce pitch of hysterical evangelistic fervor) Any money's been stolen you don't blame my ignorant husband! BLAME YOUR ATHEISTIC COMMONISTIC CHRIST-KILLER JEW ORGANIZER ${ }^{32}$.

create a very compelling dramaturgy that was rich in the details of the working man's language, habits and lifestyle. While Carl Morgan is at the center of the action in Drop Hammer, it is Dave Sigmund, the union organizer and spokesman for Manny Fried, who becomes the principle character. Twice in the play he confronts Carl about the stealing charges, and he believes his denials. Moreover, Carl has been his closest ally in the union, working for the benefits of the rank and file, and supporting Dave against the red-baiting faction who tried to destroy the local. But with the arrival of the union accountant in the final act and the examination of the ledgers and cancelled checks, it becomes clear that Carl Morgan has stolen union funds. - the brittle metal that breaks can easily be recycled - the accusations mount against Carl. He had called the bank that morning to try and prevent the release of the financial records; some of the checks were made out to cash, a violation of union rules; many checks appeared to have forged signatures. Carl appeals to Dave again not to be distracted by the charges, because even as they speak, his foreman is handing out pink slips to those whose jobs will be transferred to Kentucky. But Dave is trapped by his commitment to the rank and file, and has no choice but to hammer his good friend.

At last he breaks, and in response to Dave's plea for an explanation, Carl tries to articulate his reasons for stealing as well as confronting Dave about his privilege:

CARL: Stop sticking needles into me! (DAVE does not turn away) What the hell do you want? (Angrily) Why don't you give your big speech now about the working people 
taking over the factories and running the country? - What you forget, sir, is that everybody don't have a rich sugar daddy bother-in-law to give him a job when he gets tossed out on his ass for fighting for the poor, ignorant working class of people - Everybody don't have a rich father-in-law to toss in a nice big house for a wedding present when the daughter gets hooked with the ball and chain - Everybody don't have expensive sweaters and skirts to put on their daughters so they won't be ashamed when they go to class with all the dressed up Jew kids from high school. Sir! I'll take my medicine! What's coming to me! But if we're so damn anxious to bring everything out into the open, let's bring it all out! ... What do you want me to say? You want me to tell these selfish bastards---they'd sell both us down the river for a lousy nickel - You want me to tell them I took the money---before they could piss it all away like they did all the rest? - You think that's going to cure the situation we got over there in that shop... Okay - The party's over ${ }^{34}$.

Dave is devastated by Carl's betrayal, and by the fact that his admission of the theft will fuel all their opponents on the shop floor. Any unity in the face of the movement of jobs to Kentucky has been lost, and Dave's own integrity will be questioned again by those who oppose him. Manny Fried's long held belief that stealing was one of the easiest ways to wreck a union rebounds here in the face of those trying to do the right thing. And in assessing the consequences, Fried draws upon the profound guilt that he harbored because of his own marriage to Rhoda and her family. While it is a leitmotif in many of his works and the central subject of his Martinis and Boilermakers, nowhere does he express the anguish with more eloquence than in Carl's indictment and in the powerful and poignant conclusion of Drop Hammer.

\section{Conclusion}

Fried, who believed that "establishment theatres do not produce plays which enhance the image of labor or foreground working-class consciousness". ${ }^{35}$ was buoyed by the production and delighted by the popular and critical success. In addition to Sullivan's enthusiastic notice, William Murray wrote that,

No important American playwright I can think of has ever dealt realistically with the lives and aspirations of blue-collar workers. Our mainly middle-class writers have tended to idolize the category, usually in the pseudopoetic tradition of clifford Odets, or poke fun at it... Drop Hammer, currently being given a splendid production at LAAT, helps to fill the void. Fried knows his people too well to sentimentalize them. His workers are really dirty, they sweat real sweat; they also lie, cheat and betray each other just like the rest of us". ${ }^{36}$

Show Biz announced that Drop Hammer "works - each of its blows is resounding and meaningful; its power is fantastic and re-echoes in us." ${ }^{37}$ Variety was effusive hailing "a dynamic, often electric examination of people expressing basic responses; it's powerful stuff . . . with no ersatz tough talk, just strength laced with the humor of humanness and undoubtedly strong theatre". ${ }^{38}$ The Weekly praised the "look, sound and feel of genuine working men from their strutting sexual banter down to the dirt in their fingernails" ${ }^{39}$ There was a dissenting voice in Drama-Logue where Charles Faber wrote that, "Fried may have intended to show the oppression of the workers, but he hasn't persuaded us that the union members aren't having a rather jolly good time arguing, fighting and drinking." ${ }^{40} \mathrm{But}$ the response to the production was overwhelmingly positive echoed here in a review from the Riverside Press-Enterprise. "The various characters, down to the most minor roles, are so well portrayed and the conflicting 
personal and union loyalties so believably presented that the audience is caught up with the drama all the way through". ${ }^{41}$

For Manny Fried it was a joyous celebration. After seeing so many of his productions, short-circuited by FBI surveillance and interference, by red-baiting newspaper stories and betrayed friendships, by venal producers and timid artistic boards of directors, the success of Drop Hammer was not only tonic but hope. Bill Bushnell had given Manny a first-class production; a superb director and design team, and a cast of thirty-one speaking parts. It was the professional realization of Manny's vision and dream. But once again it tasted like ashes.

Here is how he described the aftermath in Most Dangerous Man:

Several years after that, when I ran into artistic director Bill Bushnell, he told me that he had been warned that if he ever produced another play of mine, it would be the end of his getting financial support for his theatre ${ }^{42}$.

Manny Fried's memory plays remind us how committed American corporations are to undercutting the labor movement. He is not reluctant to call out the union's own malfeasances - the stolen dues in Drop Hammer or the alcoholism in Dodo Bird, but he had seen the hard edge of capital and government power up close, and had no illusions about the determination to destroy unionism. In the current climate we would do well to heed his warnings. Unemployment is not always a mystery; it is the result of policy decisions. Free markets need to be that and not platforms for special interests. Corporate mergers eliminate competition, and without competition workers have no choice but to work for what is offered. The right to work can be framed in patriotic terms, and the old familiar commie scare, but it will become a license for more parttime employment, fewer benefits, non-paid overtime, a continually strangled middle class and a true "race to the bottom." The alternative is not eliminating unions but demanding that they be reformed to truly function on behalf of the rank and file and to oppose the Plutocracy which threatens almost all of us.

Towards the end of his life Manny went back to school, earning a PhD at Buffalo State University where he was subsequently hired to teach creative writing. He wrote continually - novels, memoires, plays and diaries. Eventually the Subversive Theatre Company in Buffalo dedicated themselves to reviving his plays and staging other works with a similar spirit of dissent. He wrote a one-man show for them - Martinis and Boilermakers - which laid bare both the professional and personal failures of his stormy life, as well as the corrosive impact of McCarthyism on his family. And he remained defiant to those who attacked organized labor. For him the trades and public worker unions were the most important contemporary forces to combat the plutocrat's accumulation of power and to protect working class men and women. Honored with the Joe Hill Award by the Labor Heritage Foundation as he approached his $98^{\text {th }}$ birthday and still smeared by others for his devotion to "communist" principles, he remained defiant:

51 And if some people don't like it - what I'm writing in accordance with what I believe is honest and true - the hell with them. So they won't produce my plays, they won't publish my novels. I'll live. And I'll write ${ }^{43}$. 


\section{NOTES}

1. Tyrone Beason, "Bargaining Power," Pacific Northwest, March 24, 2013, p. 8.

By 2014 the percentage slipped slightly to $11.1 \%$.

2. Right to work guarantees that no person can be compelled as a condition of employment, to join or not to join, nor to pay dues to a labor union.

3. David Rolf, "Seattle Leads the Chorus for a Living Wage," Seattle Times, Aug. 11, 2013, p. 11.

4. See particularly Amity Shlaes, The Forgotten Man: A New History of the Great Depression, New York: Harper-Collins, 2007.

5. As a member of the editorial board, I recall Norma's disappointment at the paucity of submissions.

6. Victor Einach, “An Investigation of Negro Employment in Buffalo," Buffalo Council of Social Agencies, Mar. 24, 1941.

7. After years of harassment, Manny sued the FBI in 1993 for one million dollars. Naming two specific agents, William Conroy and Richard Walsh, he cited "harassment, tampering, wiretapping, bullying and dirty tricks" from 1945 to 1990. Shortly after filing Special Agent Conroy died, and the suit was subsequently dismissed. Manny got no money, but through the Freedom of Information Act he was grudgingly granted more than three thousand pages of redacted files which detailed his harassment and made much of my research possible. See the Manny Fried Archive, Special Collections, Butler Library, Buffalo State University. Box 4 has significant FBI intercepts detailing their pressure on Buffalo newspapers not to cover Manny's plays or prizes.

8. Emanuel Fried, Elegy for Stanley Gorski, Buffalo, New York, Labor Arts Books, 1970, p. 15.

9. John Olszowka, "The UAW and the Struggle to Organize Aircraft, 1937-1942," Labor History, 49, 3, p. 297-317.

10. An exception is Steve Rosswurm whose book, The FBI and the Catholic Church, (2009) provides a balanced and scholarly explication of the Church and industrial labor, particularly the impact of Father Charles Owens Rice. Kimball Baker's Go to the Worker: America's Labor Apostles (2010) quotes Rice as admitting that "I talked too freely to HUAC and the FBI," p. 209.

11. Emanuel Fried, Gorski, op. cit., p. 93-94. Because Fried's plays are out of print and largely unavailable, I have quoted from them liberally here in order to give a sense of their style and language.

12. It is instructive to compare Fried's memories of the "labor priest" with the cultural memory popularized by Elia Kazan through the courageous and defiant voice of Karl Malden in On the Waterfront (1954).

13. Ibid, p. 52.

14. Ibid, p. 73.

15. Ibid, p. 99.

16. Ibid, p. 102.

17. Martin Luther King, Jr. quoted in Huffington Post, Dec. 11, 2012 from 1961 Speech.

18. Clive Barnes. "Well-Meaning Brother Gorski." The New York Times, Mar. 16, 1973, p. 34.

19. Allan Wallace. "Gorski, a unionist play, is like the worst of Odets," Yonkers Herald Statesman, Mar. 16, 1973, p. 16

20. Lou Michel. "Tonawandas backdrop for a play," Tonawanda NEWS, Jan. 16, 1981. Fried Archive, Box 14,Clipping File.

21. Anthony Chase. "Elegy for Stanley Gorski," ARTVOICE, Mar. 29, 2012. Fried Archive, Box 14, Clipping File.

22. Dan Sullivan letter to Manny Fried, Sept. 27, 1977, Fried Archive, Box 14, Folder 42. 
23. Ibid.

24. Dan Sullivan, "Echo of Odets in Hammer," Los Angeles Time, Fried Archive, Box 14, Folder 27.

25. William Murray, "Drop Hammer," New West, Jan. 28, 1980, Fried Archive, Box 14, Folder 26.

26. Manny Fried, Most Dangerous Man, p. 30.

27. Ibid, p.114.

28. Manny Fried, Drop Hammer. Cambridge, MA: West End Press, 1977, p. 42.

29. Ibid, p. 42.

30. See James B. Jacobs. Mobsters, Unions and the Feds. New York: NYU Press, 2006, p. 33.

31. Fried, Drop Hammer, pp. 44-5.

32. Ibid, p. 90.

33. Ibid, p. 92.

34. Ibid, p. 124.

35. Emanuel Fried, "Theatre and the Working Class," Political Affairs, December, 1988, p.23.

36. William Murray, "Industrial Revelation," New West, Jan 28, 1980, Fried Archive, Box 14, Folder 26.

37. D.H.R., "Drop Hammer "Show Biz, Fried Archive, Box 14, Folder 23.

38. “Tone," "Legit Review: Drop Hammer," Variety, Dec. 28, 1979, Fried Archive, Box 14, Folder 22.

39. "Drop Hammer." The Weekly, (Vol 2 No 6) Jan. 11-17, 1980, Fried Archive, Box 14, Folder 14.

40. Charles Faber. "Drop Hammer," Drama-Logue, Jan 3-9, 1980, Fried Archive, Box 14, Folder 27.

41. T.E. Foreman, "Two Plays---Very Different, Both Excellent." Riverside Press-Enterprise, Jan 12, 1980, Fried Archive, Box 14, Folder 27.

42. Fried, Most Dangerous Man, 30. Because there is little critical writing about Fried, I have relied heavily on his interviews, memoirs, correspondence and family recollections. But when encountering something that I believed needed verification, I have tried to do so. Manny was a playwright and a story-teller, and he often cast himself as the hero in his stories. I don't mean this to demean him, but rather to accept it as a part of who he was---indeed perhaps of who we all are. But I was uncomfortable reprinting this recollection about Bill Bushnell without verifying it. It was a daunting task. "Bush" as he likes to be called, left Los Angeles after the demise of the theatre center and relocated somewhere in Central or South America. With the help of my friend and playwright, Bill Mastrosimone, I was finally able to track him down in Ecuador. After some introductory conversations, Bush emailed me on Jan. 18, 2015, “I am afraid I don't remember any particular discussions with Fried. I also never felt, or at least acknowledged, any pressure not to do his work. People and governments don't threaten me much. It is a waste of there (sic) time. I did the work I wanted to do and "Drop Hammer" was the kind of big sprawling work that was about something that often appealed to me." Manny submitted several other scripts to the L.A. Actors Theatre, but there were no further productions.

43. Fried. Gorski, op. cit., 15..

\section{ABSTRACTS}

Against the background of current campaigns to undercut industrial labor unions in the United States and to isolate wealth in the fabled "one-percent," Barry Witham explores the workingclass plays of Emanuel "Manny" Fried who contested these same forces thirty years earlier. Fried was blacklisted after a celebrated appearance before the House Committee on Un-American 
Activities, but retaliated against the FBI and the Catholic Church by documenting in dramatic form his harassment and the suppression of the labor union movement. His memory plays recall a turbulent era which still haunts our culture.

Au regard du contexte socio-politique actuel et des tentatives déployées aux Etats-Unis afin de non seulement affaiblir les syndicats de travailleurs mais également de maintenir les prérogatives des richissimes "un pourcent", Barry Witham analyse les mises en scène de la classe ouvrière dans les pièces de «Manny » Fried qui dénonçait, trente ans plus tôt, ces mêmes injustices. Le nom de Fried fut inscrit sur la liste noire du gouvernement après une apparition remarquée devant la House Committee on Un-American Activities (littéralement « Commission de la Chambre sur les activités antiaméricaines»). Il se vengea du FBI et de l'Eglise Catholique en écrivant une pièce documentaire sur les abus dont il fut victime et la répression contre les mouvements ouvriers. Ses pièces « mémoire » ravivent une époque agitée qui hante encore notre culture.

INDEX

Keywords: Catholicism, FBI, Labor plays, black list, government, memory, worker Subjects: Theater

Mots-clés: Eglise Catholique, FBI, labor plays, liste noire, gouvernement, mémoire, ouvrier

\section{AUTHOR}

BARRY B. WITHAM

Emeritus Professor

University of Washington (USA) 